\title{
DIAGNOSIS OF “PROBABLE” STILL'S DISEASE AND ITS OUTCOME
}

\author{
BY \\ BARBARA M. ANSELL AND E. G. L. BYWATERS \\ M.R.C. Rheumatism Research Unit, Canadian Red Cross Memorial Hospital, Taplow, Berks
}

To inform ourselves on the prognosis of Still's disease, all referrals to this Unit from 1947 to January, 1959, in whom this diagnosis had been seriously considered were reviewed. Those cases in whom initial examination and investigation revealed some other disorder, such as slipped femoral epiphysis, Thieman's syndrome, or leukaemia, or in whom no abnormality could be detected on admission here were excluded. A diagnosis of definite Still's disease was made only if our usual criteria were satisfied: namely, arthritis commencing before the age of 16 years with evidence of at least four joints involved for a minimum of 3 months or, when fewer joints were involved, histological evidence of rheumatoid arthritis. Cases with such other disease as disseminated lupus erythematosus, ankylosing spondylitis, psoriasis, ulcerative colitis, or polyarteritis nodosa were excluded.

Of the total of 269 cases reviewed, 219 fulfilled the criteria cited at the time of their discharge from hospital, while psoriasis had been discovered in three and ulcerative colitis in two. The remaining 45 were considered to be suffering from "probable" Still's disease. This label was applied to cases of arthralgia or synovitis with an erythrocyte sedi- mentation rate (E.S.R.) raised above $19 \mathrm{~mm}$./hour, frequently accompanied by fever, rash, and lymphadenopathy, and occasionally by pericarditis or pleurisy for which no other cause could be found. Five patients, three with definite and two with probable Still's disease, were not followed further as their own physicians wished to supervise their care exclusively, but the rest were followed to date, usually at yearly intervals unless they needed to be seen more often. The follow-up of those with definite Still's disease has already been published (Ansell and Bywaters, 1959). The result of the follow-up of the 43 cases classed as probable Still's disease is described here. The mean duration of follow-up in these cases is 5.9 years (range 2 to 11 ), 28 having completed a 5-year follow-up. These cases seemed to us to be of interest, since the present custom of taking and following classical groups and omitting all further mention of the many interesting patients who do not fit defined criteria, appears to be growing.

\section{Results}

The various re-appraisals from the initial discharge date to January, 1959, and again from then to the present time are shown in Table I.

TABLE I

INITIAL DIAGNOSIS AND FOLLOW-UP

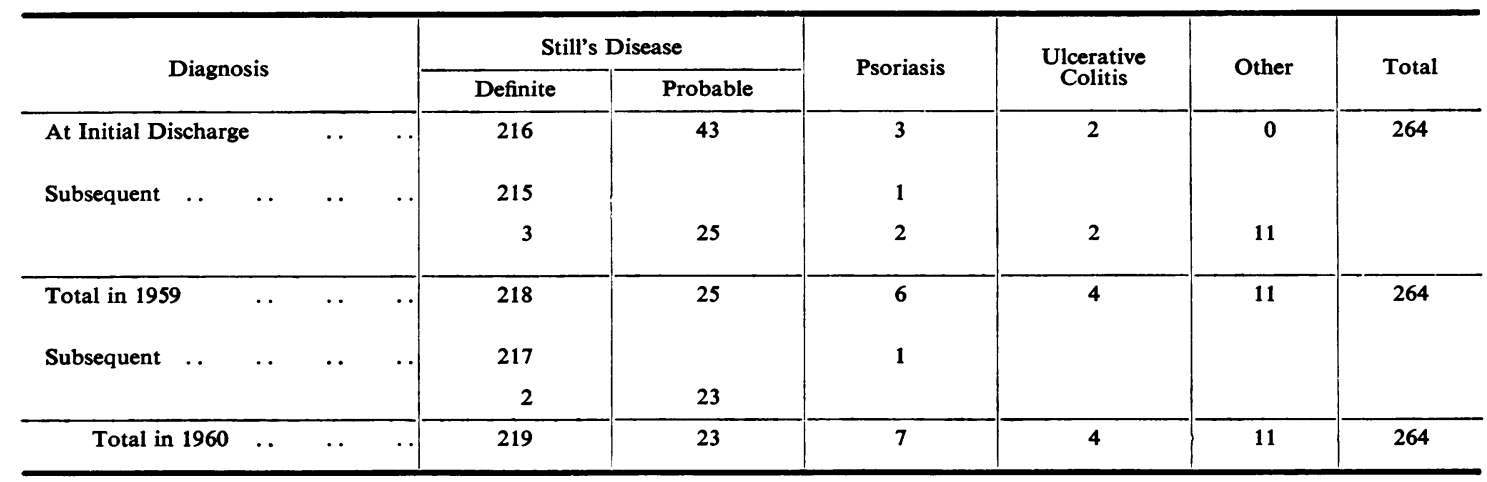


Two patients originally thought to have probable Still's disease have since developed psoriasis (as did two originally classed as definite Still's disease), five have shown further diagnostic criteria and are now classed as definite Still's disease, two have ulcerative colitis, and in eleven some other diagnosis has been reached (the details are given in Table II).

TABLE II

ELEVEN PATIENTS IN WHOM ANOTHER DIAGNOSIS WAS MADE

\begin{tabular}{|c|c|c|c|c|c|c|}
\hline \multicolumn{2}{|c|}{ Ankylosing Spondylitis } & $\cdots$ & $\cdots$ & . & $\cdots$ & 2 \\
\hline Rheumatic Fever* & $\cdots$ & . & $\cdots$ & . & $\cdots$ & 2 \\
\hline Osteochondritis & . & $\ldots$ & $\ldots$ & . & $\cdots$ & 2 \\
\hline \multicolumn{2}{|l|}{ Probably Infectious. } & $\cdots$ & $\cdots$ & . & $\cdots$ & 1 \\
\hline \multicolumn{6}{|c|}{ Raynaud's Phenomenon with Positive D.A.T. } & 1 \\
\hline \multicolumn{3}{|c|}{ Systemic Lupus Erythematosus } & $\cdots$ & . & $\cdots$ & 1 \\
\hline Dermatomyositis & . & $\ldots$ & $\ldots$ & $\ldots$ & $\ldots$ & 1 \\
\hline \multirow{2}{*}{$\begin{array}{r}\text { Scleroderma } \ldots \\
\text { Total }\end{array}$} & $\ldots$ & $\ldots$ & $\ldots$ & $\ldots$ & $\cdots$ & 1 \\
\hline & .. & $\ldots$ & $\ldots$ & $\ldots$ & $\ldots$ & 11 \\
\hline
\end{tabular}

* A total of 1,434 cases of rheumatic fever were admitted during the same period.

Ankylosing Spondylitis.-A definite diagnosis was made only when there was clinically detectable spinal involvement as well as bilateral radiological sacro-iliac changes. Both these patients, who were aged 10 and 12 respectively, presented as cases of transient polyarthritis. One had no residual deformity at 6 years from onset, and the other had a metatarsal growth defect at 5 years from onset, when back symptoms developed.

Rheumatic Fever.-Of the two patients subsequently diagnosed as cases of rheumatic fever, one was originally admitted with acute polyarthritis in one wrist and the metacarpophalangeal joints which persisted for 6 weeks. There was no evidence of carditis but there was a history of a sore throat and the antistreptolysin-O titre was $833 \mathrm{u} . / \mathrm{ml}$. In the absence of clinical and radiological joint residua it seemed wiser to conclude that this illness was rheumatic fever.

In the other case, the initial diagnosis of probable Still's disease was made because of a rash somewhat like that seen in Still's disease, joint involvement had persisted for only 3 weeks, there was no carditis, and the antistreptolysin-O titre was $200 \mathrm{u}$./ml. 8 months later the patient was re-admitted with classical erythema marginatum, mild polyarthritis, and $c$ carditis, and in the 3-year follow-up period the cardiac murmur has persisted.

Osteochondritis.-Both the patients who developed osteochondritis presented with persistent kneo effusions, bilateral in one. There were no radiog logical changes initially and biopsy showed milo traumatic synovitis. The changes which developed in the patella in one of these cases over a 6-month period are shown in Fig. 1.
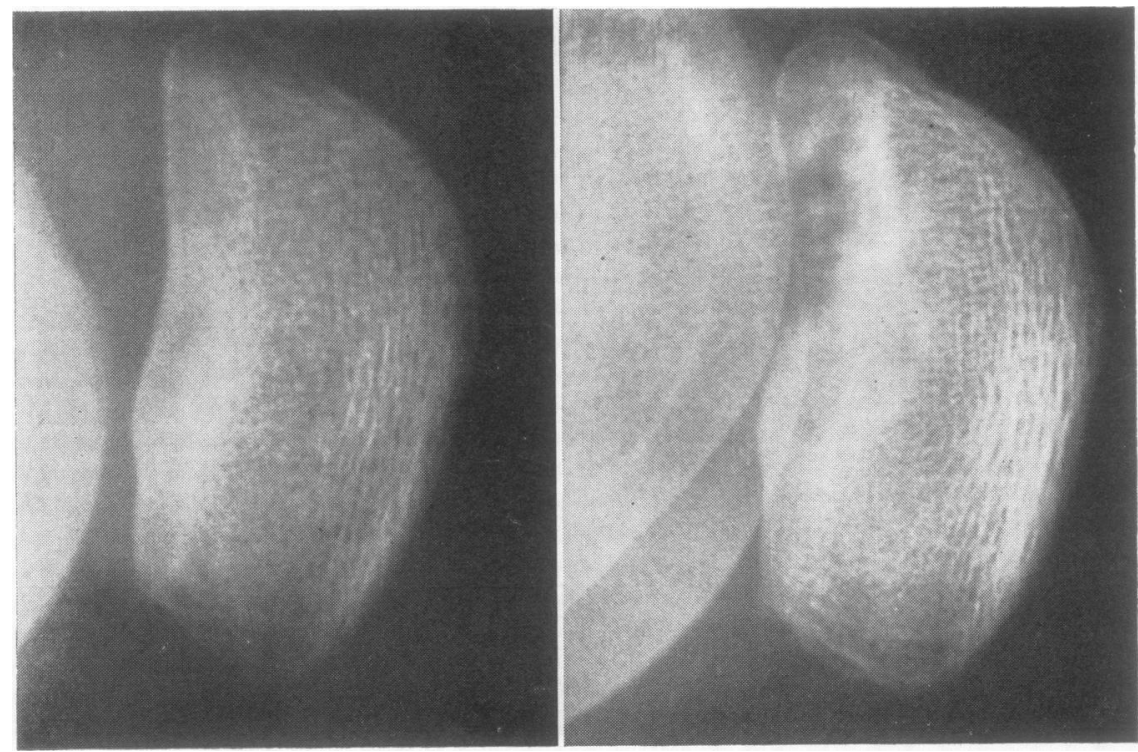

Fig. 1.-Changes in the patella occurring during a 6-month period in a girl with osteochondritis. 
Raynaud's Phenomenon.-This case is unusual in that this little girl was seen in 1952 at the age of 11 with a 4 months' history of swollen joints associated with the recent onset of Raynaud's phenomenon. No joint involvement was evident on admission, but the erythrocyte sedimentation rate (E.S.R.) was raised to $40 \mathrm{~mm} . / 1$ hour (Westergren) and the differential agglutination titre (D.A.T.) was positive at 1:32. Transient joint swelling was recorded on two separate occasions in the next 8 years without clinical or radiological residua, and she continued to have severe Raynaud attacks, a continuouslyraised E.S.R., an intermittently-positive D.A.T., a positive latex test, and a positive anti-nuclear fixation test without lupus erythematosus (L.E.) cells. Because of the possibility of digital arteritis (Scott, Hourihane, Doyle, Steiner, Laws, Dixon, and Bywaters, 1961), a brachial arteriogram was performed in 1960 but showed no abnormality.

Systemic Lupus Erythematosus.-The history of this girl began with pleurisy in 1945 , when she was aged 12. A diagnosis of probable Still's disease was made when she was seen in 1947 , because of arthralgia, fever, substernal pain, and Raynaud's syndrome. The next year she had an attack of arthritis associated with marked lymphadenopathy, and she continued to suffer with arthralgia from time to time. In 1953 she was re-admitted with fever, polyarthritis, pericarditis, peripheral cyanosis, and peeling of the skin on the finger tips, and the E.S.R. was then raised to $115 \mathrm{~mm}$./1 hour. The diagnosis of systemic lupus erythematosus was seriously considered, but no L.E. cells could be found. She recovered after 2 months on salicylate therapy and continued on this medication for the next 3 years. In 1957 she was re-admitted with a

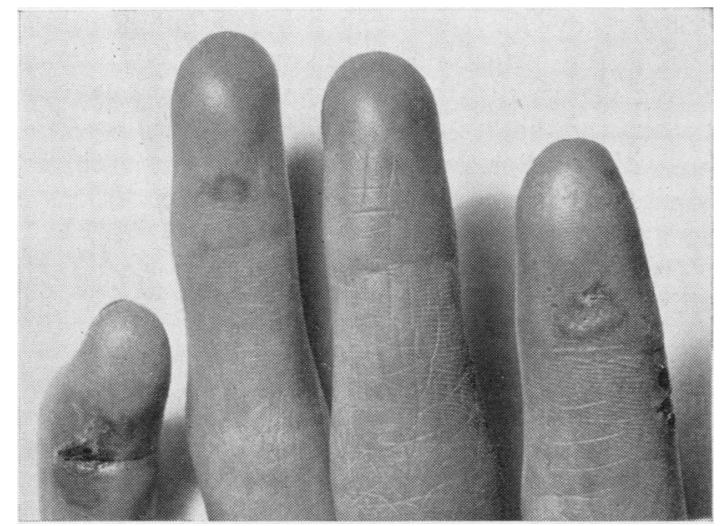

Fig. 2.- "Chilblain" lupus erythematosus 11 years after the onset of arthralgia. recurrence of pericarditis and bilateral pleural effusions. The white blood count, previously normal, had now fallen to $2,900 / \mathrm{c} . \mathrm{mm}$. with 40 per cent. polymorphs, and the D.A.T. was positive for the first time at $1: 64$, but again L.E. cells were not found, although they were looked for on at least ten occasions. In 1958 she developed painful spots on the fingers (Fig. 2), diagnosed as chilblain lupus and an aortic diastolic murmur was heard for the first time. The E.S.R. was now $60 \mathrm{~mm}$. $/ 1$ hour and the D.A.T. 1:64 and although L.E. cells could still not be found, the antinuclear factor was strongly positive. The hands and feet have been radiologically normal throughout.

Dermatomyositis.-This girl was first seen at the age of 9 years with pain in the ankles and knees followed by the development of nodules around the ankles (Fig. 3). No arthritis was present, the E.S.R. was normal and the D.A.T. negative, and histology of a tendon-sheath nodule showed merely bland fibrinous change. Over the next 3 months she developed severe pain on walking followed by progressive weakness of the legs and coldness of the hands and feet with a scaling telangiectatic rash on the face and hands with "collodion" patches on the knuckles. She has subsequently done well on steroid therapy with only some residual weakness of the muscles of lower limbs and the grip.

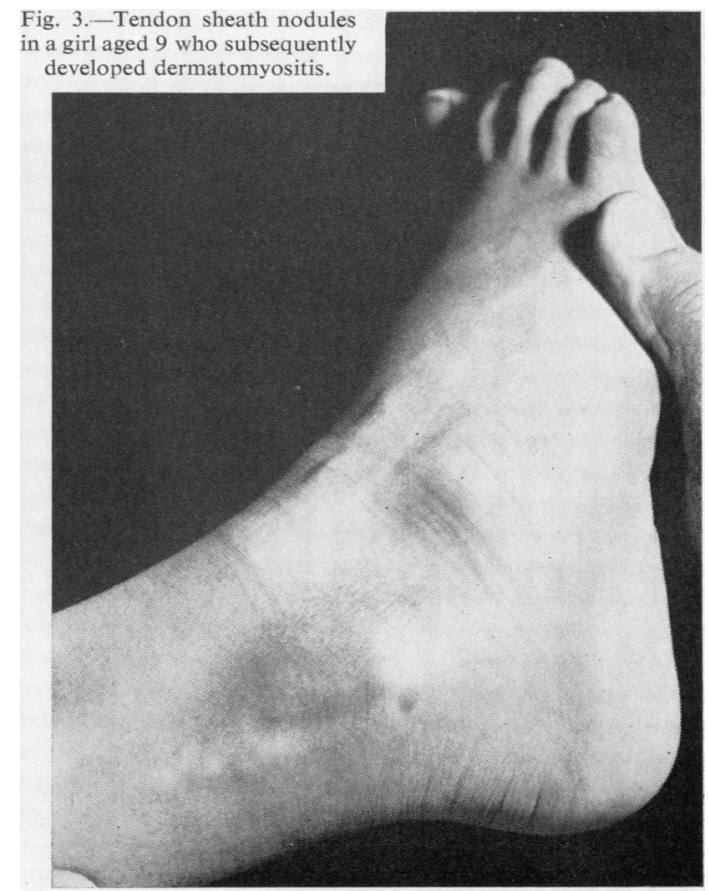


Scleroderma.-This patient was also atypical. Her first symptoms were pain and stiffness in the feet, hands, and wrists, with functional difficulty. When she was first seen in 1951 at the age of 13, there was limitation of movement of the wrists, but no swelling; the E.S.R. was normal and the D.A.T. negative. The first patch of scleroderma (Fig. 4) developed 3 months later and numerous patches subsequently developed. These would appear suddenly, spread quickly for a few days, and affect both arms and the upper part of the trunk. No new patch has occurred in the last 3 years and during her first pregnancy-now a year ago-all the areas became much softer and less well defined but they

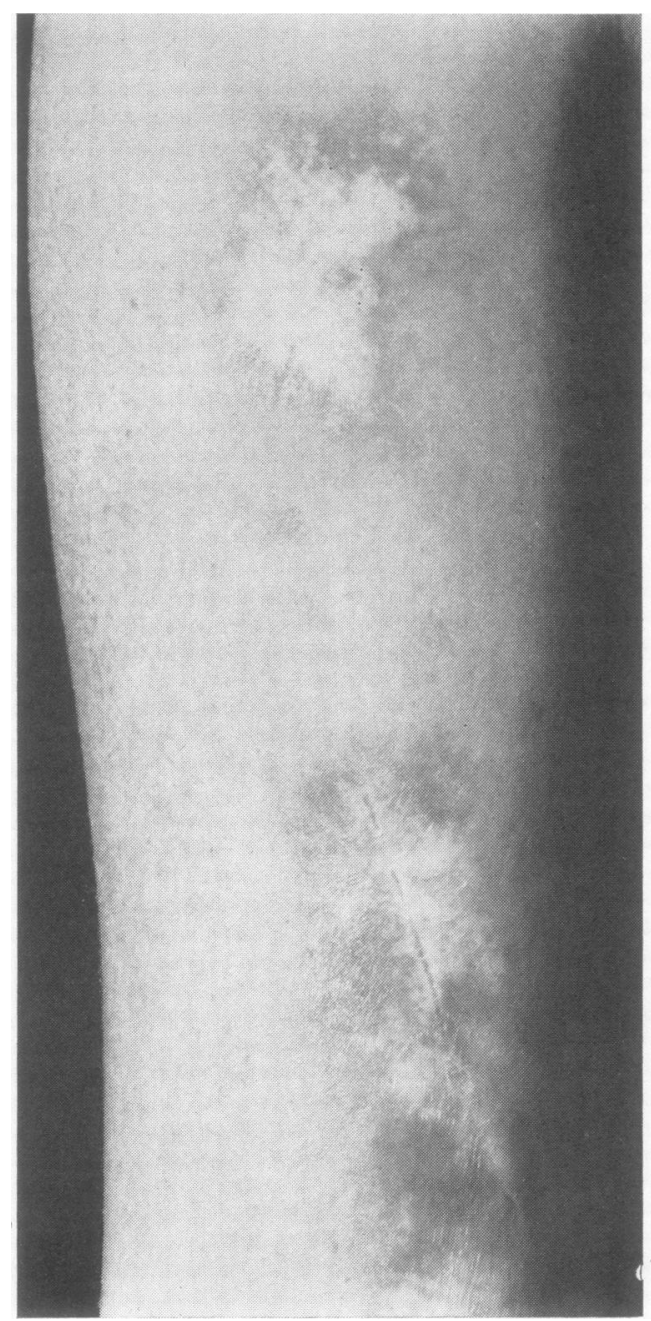

Fig. 4.-Patches of scleroderma which developed in a 13-year-old girl. are still scarred and depigmented. At no time has there been any evidence of systemic sclerotic disease.

Ulcerative Colitis.-Of the four patients in whom a final diagnosis of arthritis associated with ulcerative colitis was made (Table I), two had symptoms which were more or less concurrent, and the other two, initially diagnosed as probable Still's disease, showed bilateral knee effusions which antedated the colitis by 3 and 2 years respectively.

In all four cases, joint symptoms have remitted, although the colitis is still active in one and three show radiological changes in the sacro-iliac joints (Steinberg and Storey, 1957; Bywaters and Ansell, 1958).

Psoriasis.-In this group, two of the three cases presenting as psoriatic are now in remission with minimal residua but one has severe crippling disease.

A fourth girl developed apparently typical Still's disease at 13 years of age in 1950, the only unusual feature being the involvement of the proximal interphalangeal joints of several toes in 1953. The disease continued active and maintenance cortisone was started in 1955. An exacerbation of arthritis occurred in 1956 and for the first time, 6 years from the onset, she developed psoriasis, and 2 years later showed a positive D.A.T. and latex-fixation test In 1958, because of severe activity in both joints and skin, she was given triamcinolone with an excellent response, so that to-day, despite clinical and radiological residua in many joints, including the sacroiliac, she is able to lead a normal life on a maintenance dose of triamcinolone $4 \mathrm{mg}$. daily. The D.A.T. became negative in 1959 and the latexfixation test in 1960 .

The fifth case was also originally diagnosed as one of definite Still's disease; she had polyarthritis followed by the development of bilateral iridocyclitis for which she has required continuous steroid therapy for the past 6 years. 11 years from the onset, while on prednisone for the iridocyclitis, and with all joints quiescent, she has now developed psoriasis. The D.A.T. and latex-fixation test have been negative throughout.

The sixth and seventh patients, who were both initially diagnosed as cases of probable Still's disease both presented with knee effusions. One, a girl aged 8 at the onset in 1949, had recurrent effusions until 1954, when they became persistent, and a year later she developed florid psoriasis followed after a few months by a severe polyarthritis. The condition in the skin and joints is now in remission, but there are clinical residua and erosions and subluxation are visible in $x$ rays of 
the hands and feet. The other child had bilateral knee effusions at the age of 15 which resolved over 2 years leaving no clinical residua, but sacro-iliac change is apparent radiologically.

Probable Still's Disease.-Of the original 43 patients diagnosed as cases of probable Still's disease, 23 still remain in this category and these cases appear to fall into three groups (Table III).

TABLE III

CLASSIFICATION OF 23 CASES REMAINING IN CATEGORY “PROBABLE STILL'S DISEASE" IN 1960

\begin{tabular}{|c|c|c|c|c|c|c|}
\hline "Benign Systemic & Disease' & , & $\cdots$ & $\cdots$ & $\cdots$ & 10 \\
\hline “Oligo-arthritis" & $\cdots$ & $\cdots$ & $\cdots$ & $\cdots$ & $\cdots$ & 9 \\
\hline \multicolumn{3}{|c|}{ "Transient Febrile Polyarthritis" } & $\cdots$ & $\cdots$ & $\ldots$ & 4 \\
\hline Total & $\ldots$ & .. & . & .. & .. & 23 \\
\hline
\end{tabular}

In the first group of ten cases, designated "benign systemic disease", constitutional signs were marked, with fever, Still's rash, and lymphadenopathy, and minimal symptoms and signs in the joints. In the second group, designated "oligo-arthritis", less than four joints were involved. In the third group, designated "transient febrile polyarthritis", the duration of polyarthritis was less than 3 months and constitutional symptoms were mild or absent. The D.A.T., transiently positive initially in three out of 22 at a titre of $1: 16$, was negative at last follow-up in all 22 who were tested. This initial incidence is similar to the finding in our cases of definite Still's disease in which the initial D.A.T. was positive in 13 per cent. of cases (Bywaters, Carter, and Scott, 1959).

(a) The pattern of illness classed as "benign systemic disease" is illustrated by the case of a boy aged 3 who had been ill for 14 days when admitted. The course of his illness is shown in Fig. 5. He had the type of fever considered to be characteristic

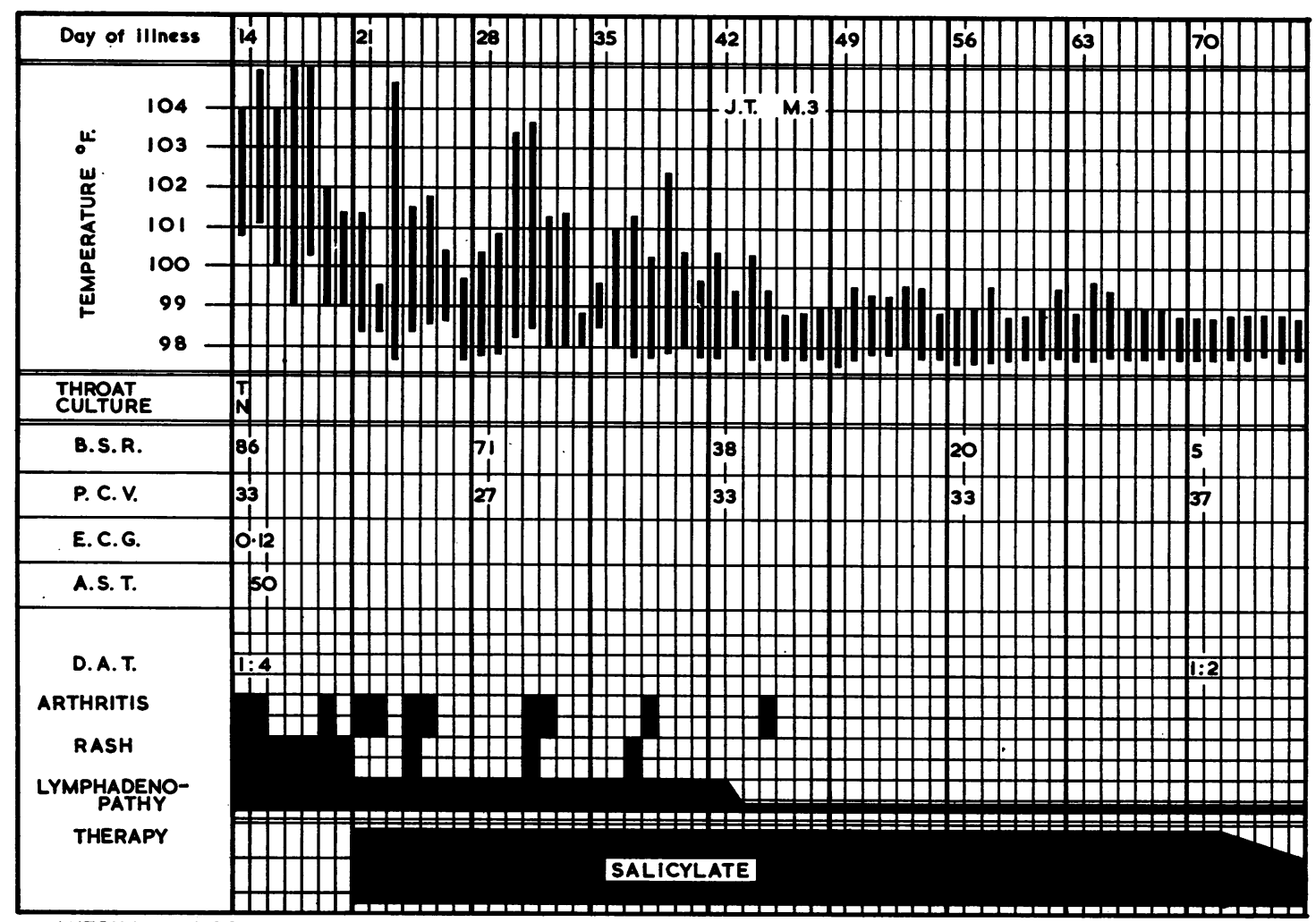

MANTOUX 1: 10,000 Neg.

Fig. 5.-Chart showing the course of one patient designated as a case of "benign systemic disease". 
of Still's disease with a wide daily swing (McMinn and Bywaters, 1959), a raised E.S.R. with a normal antistreptolysin-O titre and negative D.A.T., transient arthritis rash, particularly when the fever was marked, and generalized lymphadenopathy. There was a gradual regression of these symptoms, so that he became completely well in 10 weeks, and there have been no further episodes during the period of follow-up, which is now 7 years.

This type of fever was seen in all ten cases, the typical macular rash (Fig. 6) (Isdale and Bywaters, 1956) in nine, generalized lymphadenopathy in seven, splenomegaly in three, pericarditis in two, and pleurisy in one. All had arthralgia and seven showed arthritis with one or more joints involved for 2 to 3 days. Joint biopsy in one patient showed a mild synovitis with many polymorphs, but only a few plasma cells. The disease appeared to be selflimiting and to last 3 to 4 months, and all the patients except one have now completed a 5-year follow-up without clinical residua and without radiological residua in the hands (10), feet (9), or cervical spine (5) which were examined.

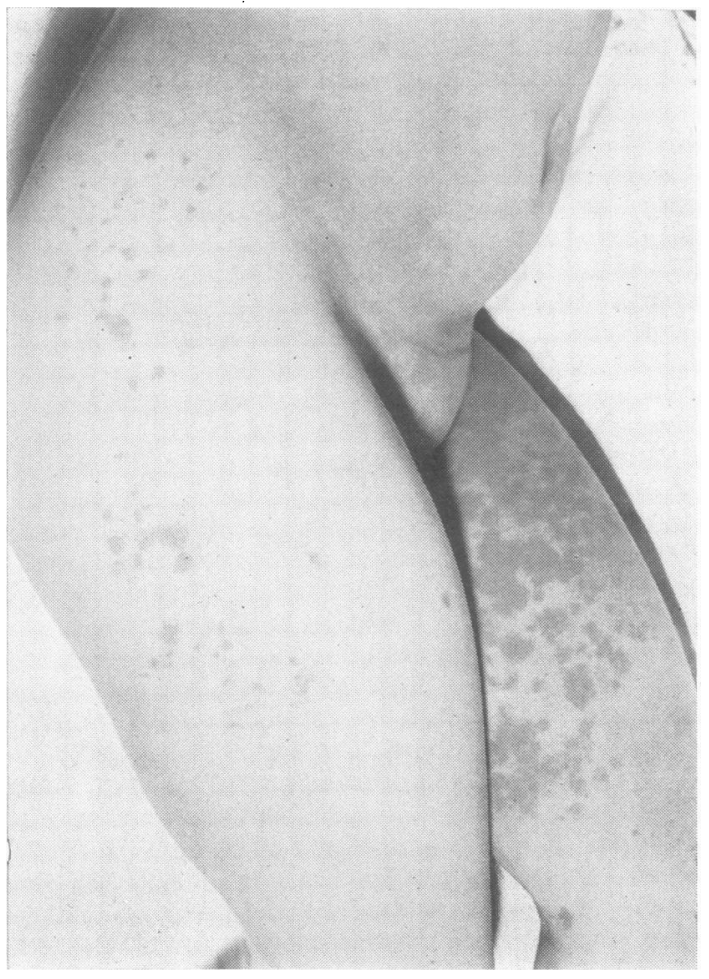

Fig. 6.-Typical Still's rash. (b) In the nine cases in the "oligo-arthritis" group $\frac{5}{3}$ any joints could be affected (Table IV).

TABLE IV

FEATURES OF NINE CASES OF OLIGO-ARTHRITIS

\begin{tabular}{|c|c|c|c|c|}
\hline Bilateral knee effusions & . & .. & .. & 3 \\
\hline Unilateral knee effusions & .. & .. & . & 2 \\
\hline Cervical Spine + Iritis & . & .. & . & 1 \\
\hline Hip and Ankle & . & .. & . & 1 \\
\hline Wrist and Pericarditis & . & .. & .. & 1 \\
\hline $\begin{array}{l}\text { Metatarso-phalangeal Joi } \\
\text { synovitis } \ldots\end{array}$ & $\begin{array}{l}\text { ats a } \\
\ldots\end{array}$ & $\begin{array}{l}\text { Bi } \\
\cdots\end{array}$ & $\begin{array}{c}\text { ral Teno- } \\
\ldots\end{array}$ & 1 \\
\hline Total & $\ldots$ & . & .. & 9 \\
\hline
\end{tabular}

Patients with bilateral knee effusions have been $\stackrel{\text { 은 }}{\rightarrow}$ followed for from 3 to 6 years and those with uni- $c s$ lateral effusions for from 4 to 11 years without $\frac{\mathbb{}}{0}$ development of further signs or symptoms: radio- $\stackrel{\mathbb{\Phi}}{\vec{D}}$ logically the knees and sacro-iliac joints are normal. 음 The boy who presented at the age of 10 years with $\stackrel{\Phi}{-}$ transient hip involvement may well have ankylosirfo $\overrightarrow{0}$ spondylitis, as he has had bilateral sacro-ilien changes for 8 years, but there is as yet no evidence of spinal involvement. In the last two cases, residual clinical and $x$-ray changes were present at follow-up in the wrist of one and in the foot of the other. Fig. 7 (opposite) shows the radiological $\frac{\otimes}{\otimes}$ changes in the wrist in the girl who presented with arthritis of both wrists, pericarditis, and fever. She $\frac{0}{3}$ was treated with cortisone for 12 weeks and is now symptom-free but with residual limitation of movement of this wrist.

(c) The group of four cases presenting with polyarthritis, accompanied by fever and in one case 3 . by lymphadenopathy, may well represent mild Still's disease. An example of this form of the disease 3 was a 2-year-old boy who had arthritis affecting 0 both knees, hands, and wrists, associated with fever? and lymphadenopathy which was followed by $\frac{7}{0}$ occasional swelling of a wrist and knee for a year. Initially, the $x$ rays were normal, but over the next $\tilde{N}$ 10 years changes developed in the cervical spine $N$ (Fig. 8, opposite). The only clinical residuum is a N slightly underdeveloped chin. However, another ${ }_{\sigma}^{\omega}$ girl had a febrile polyarthritis complicated by iritis lasting for 10 weeks and is now well, but she shows marked sacro-iliac changes and could be regarded as a possible case of ankylosing spondylitis but without ${ }^{+}$ spinal involvement. 


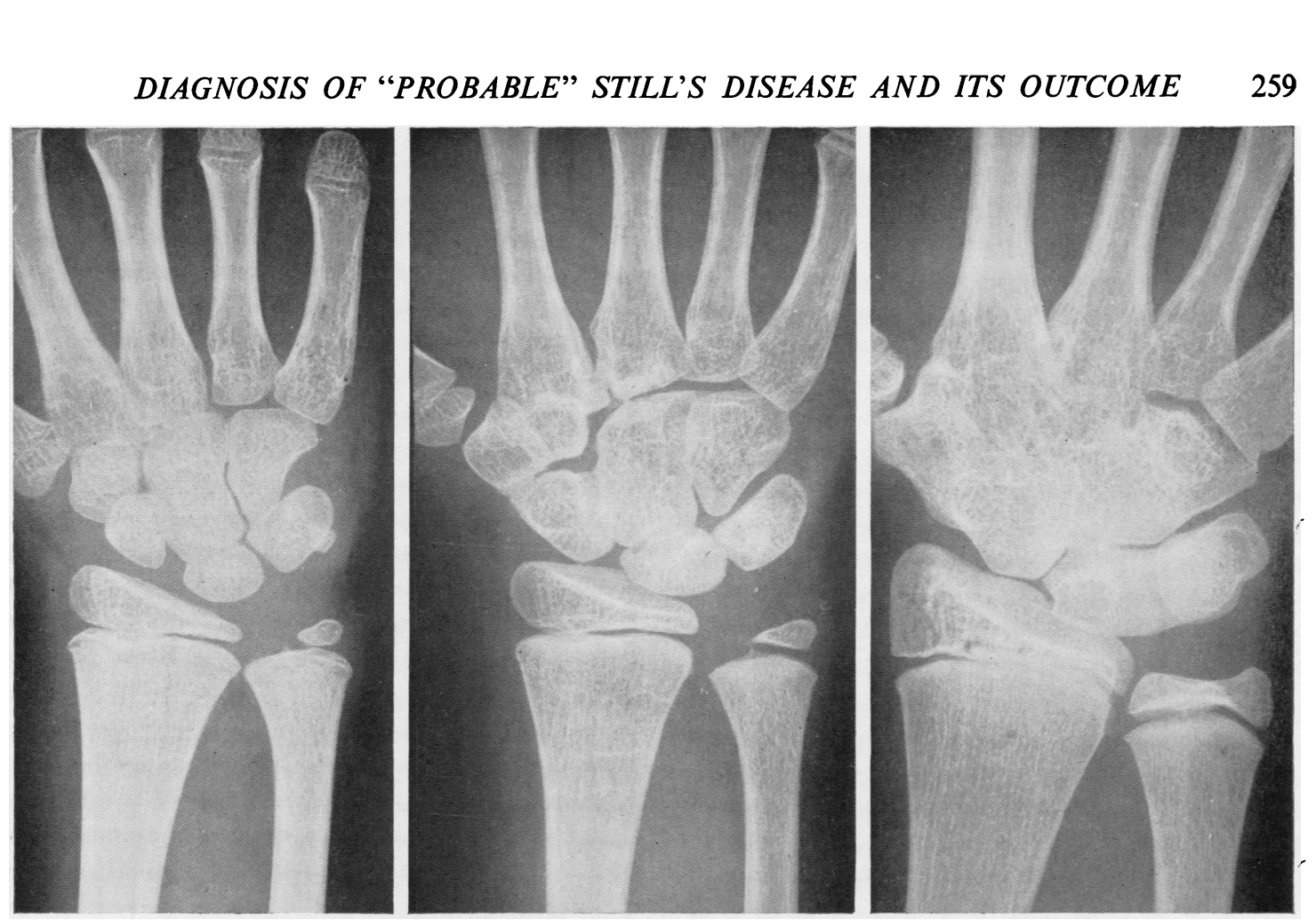

Fig. 7.-Progressive radiological change seen during a 6-year period in the left wrist in a girl who presented with oligo-arthritis and pericarditis.

Fig. 8.-Bony fusion of apophyseal joints five and six and commencing fusion of the fifth and sixth vertebral bodies, 10 years after a short attack of polyarthritis.

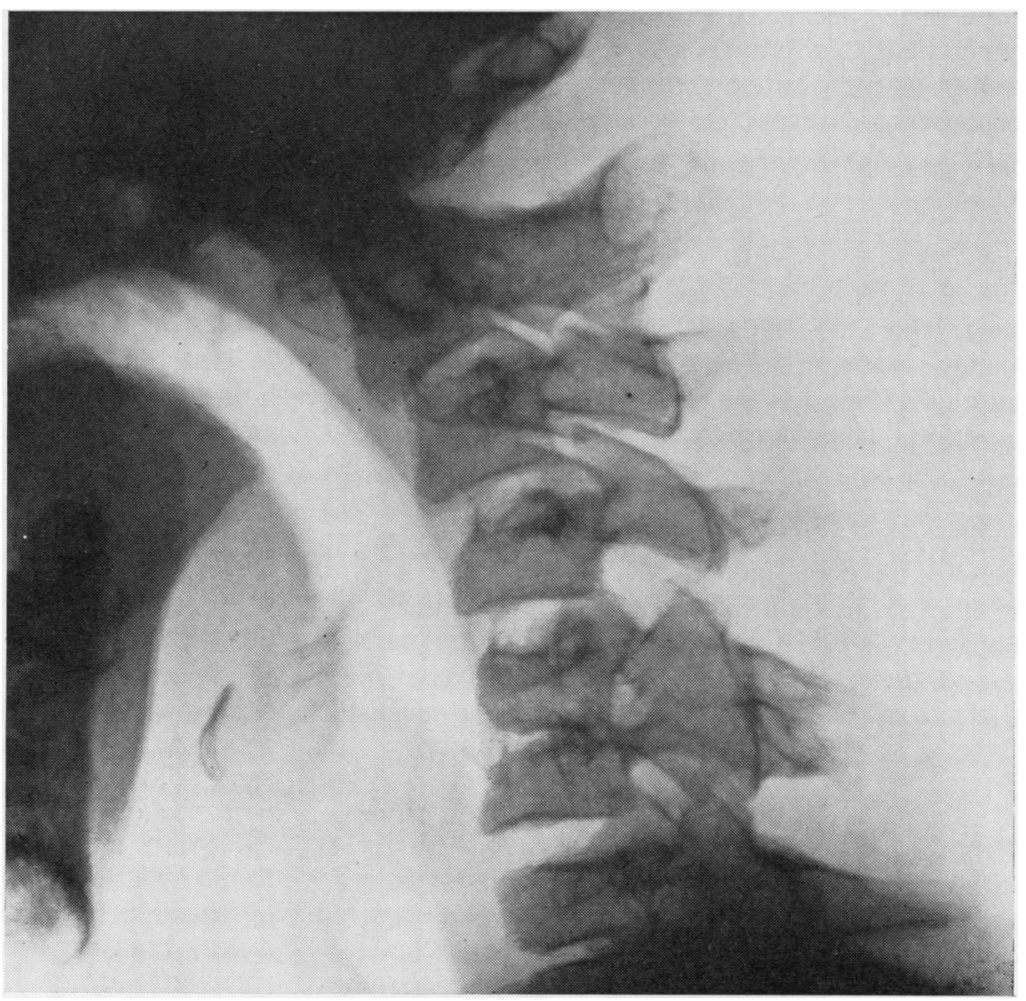




\section{Discussion}

The problems encountered in the diagnosis of atypical arthritis, particularly transient arthritis, are well illustrated by the follow-up of these patients. Of the inirial 43 , only five have gone on to typical Still's disease; in fifteen some other diagnosis has been made and 23 remain in the "probable" category.

Psoriasis may develop at a very early age, the youngest patient recorded by Church (1958) being 3 weeks old, but the maximal incidence is between the ages of 5 and 20 years (Church, 1958). The skin lesions have been noted to follow the joint lesions in some 23 per cent. of cases (Wright, 1956). It is not, therefore, surprising that some of our patients have developed psoriasis during the follow-up period and should be more properly classed as cases of psoriatic arthritis. Although, in a classical case, psoriatic arthritis presents quite marked differences from rheumatoid arthritis, there are many patients in whom differentiation is difficult and some, in fact, in whom the Rose-Waaler and the latex-fixation tests are positive. These latter may be cases of a chance association of two diseases, and this has been fully discussed by Wright. Perhaps the most important differentiating features are the involvement of the proximal interphalangeal toe joints, but our patient in whom these joints were involved had had transient positive serological findings. Of the other seven cases with psoriasis, one has developed a rapidly destructive disease with severe crippling and the remainder have had a mild course, usually with recurrent attacks involving only a few joints and clearing up with minimal clinical and radiological residua. With the exception of the one case quoted here, the D.A.T. was persistently negative in these patients. The only importance in making such a differentiation is, in general, the milder prognosis which such cases show.

Ulcerative colitis does occur in childhood, although not as frequently as in adult life, the peak incidence in childhood is about 8 or 9 years, but the disease may start during the first year of life. In the series published by King, Lindner, and Pollard (1959), 13 per cent. were aged 15 years or less at onset, the earliest starting at the age of 5 . Arthritis was the most frequent complication in the juvenile series reviewed by Platt, Schlesinger, and Benson (1960), occurring in 17 per cent. of their 62 cases. It is interesting to note that in three of Platt's cases and in seven of our series of arthritis with colitis (Bywaters and Ansell, 1958), the arthritis preceded the colitis. Colitis should be suspected in the absence of overt gastro-intestinal symptoms, if there is bowel frequency above the normal range, erythema nodosum, involvement of the small toe joints, or migratory and transient synovitis recurrent $\underline{\text { 으. }}$ over a number of years in the absence of signs of $\stackrel{\bar{c}}{?}$ rheumatic fever. Sacro-iliac involvement may also $\overrightarrow{\vec{N}}$ occur, as in three of the four cases described in this paper.

Crohn's disease may also occur in childhood, and $\frac{\bar{\sigma}}{\bar{\omega}}$ in adults at any rate may be associated with a type $\overrightarrow{\mathbb{D}}$ of arthritis similar to that seen in ulcerative colitis.

Effusions, usually in the knees, may be the presenting feature of osteochondritis, and may precede $\vec{O}$ $x$-ray changes. Biopsy here usually shows a $\overrightarrow{\vec{H}}$ traumatic type of synovitis. Osteochondritis dessi- $\vec{\sigma}$ cans is frequently bilateral, affecting the knees, although not necessarily simultaneously. It may be familial (Smith, 1960). The majority of patients - are males (Green and Banks, 1953). We have $\omega$ also cared for one patient presenting as a case of ज్ Still's disease with what appeared to be a typical ${ }^{\mathscr{C}}$ Still's rash from the first day of life, in whom the bilateral knee pain and swelling was due to epi- $\vec{c}$ physitis of the tibial epiphyses.

Ankylosing spondylitis can start at an early age, $\stackrel{\mathbb{D}}{\mathbb{D}}$ as shown by Hart (1955); in sixteen of his 184 cases it started between the age of 10 and 15 years. 으 Edström, Thune, and Wittbom-Cigén (1969) $\vec{\bullet}$ recorded three boys in whom it started at the a of 5, 8, and 12. Transient polyarthritis, ofter diagnosed as rheumatic fever, is being increasing recognized as a forerunner of ankylosing spondylitis, so that when reviewing the problem of heart involvement in ankylosing spondylitis, Hollister and $\frac{\mathrm{O}}{\mathrm{D}}$ Engleman (1958) recorded polyarthritis without $\varrho$ joint residua in 25 per cent. of 98 cases of ankylosing $\overrightarrow{\vec{O}}$ spondylitis, while only six had cardiac residua, $\exists$ suggesting that this polyarthritis was rheumatic fever.

All the above conditions are comparatively rare, however, compared with rheumatic fever, and this sometimes presents quite a difficult problem of $\frac{0}{\sigma}$ differentiation. This diagnosis usually becomes 3 . obvious, however, during the patient's stay inc hospital, and in fact the two patients in this series, wrongly diagnosed as cases of Still's disease, in $\mathrm{O}$ whom a retrospective diagnosis of rheumatic fever was made, represent a very small fraction of the 1,434 cases diagnosed as rheumatic fever over the same period. Important differentiating points are $\mathcal{N}$ age (rheumatic fever seldom occurring before the $N$ age of 5, whereas Still's disease frequently does), the N presence of high remittent fever in Still's disease $\omega$ (McMinn and Bywaters, 1959), and the typical Still's rash (Isdale and Bywaters, 1956); the presence of carditis, a positive antistreptolysin-O titre and $\mathbb{\Phi}_{\infty}$ a very high erythrocyte sedimentation rate suggest ${ }^{+}$ rheumatic fever. 
Diagnosis of the less common collagen diseases, such as dermatomyositis, scleroderma, and systemic lupus erythematosus, may be difficult to establish, particularly when the manifestations are atypical, and this is borne out by the duration of follow-up required.

Reiter's syndrome may also occur in childhood (Jacobs, 1961). The presence of conjunctivitis, diarrhoea, dysuria, etc., should suggest this rather rare probability. There was no such case in this series.

Sarcoidosis is another possibility. This may or may not be associated with erythema nodosum as a transient and sometimes recurrent synovitis, and suspicion should be aroused if there is a negative Mantoux test with hilar gland enlargement. Confirmation is by Kweim test or by biopsy of scalene node, liver, or muscle.

The arthritis of sickle-cell anaemia is not seen in Great Britain except in centres of immigration. Virus infections such as mumps may be associated with polyarthritis, but this is mainly seen in adults (Appelbaum, Kohn, Steinman, and Shearn, 1952) and synovitis with rubella also occurs mainly in young adults. Fungus infections are rare in children, as are specific bacterial infections (Morse and Pryles, 1960).

\section{Summary}

Of 43 cases with features suggestive of Still's disease seen before January, 1959, and followed to date, five have developed classical Still's disease, and in a further fifteen other diagnoses have been made, including psoriatic arthritis, ulcerative colitis, ankylosing spondylitis, disseminated lupus erythematosus, scleroderma, and dermatomyositis.

During the same period 219 cases of definite (defined) Still's disease were seen, only two of which have subsequently had to be removed from this category owing to the later development of psoriasis.

The 23 who remain in the category of "probable Still's disease" can be divided into three groups:

(a) Those with oligo-arthritis but joint residua;

(b) Those with a more generalized but transient polyarthritis with minimal residua who may well have had a mild form of the disease;

(c) Those who presented with systemic manifestations and remitted completely, who possibly had a forme fruste of the disease.

However, as almost one-third of the patients originally classed as cases of probable Still's disease have been placed in other categories at follow-up, it would seem wise, certainly for research purposes, to continue to use strict criteria before making a definite diagnosis.

\section{REFERENCES}

Ansell, B. M., and Bywaters, E. G. L. (1959). Bull. rheum. Dis., 9, 189.

Appelbaum, B., Kohn, J., Steinman, R. E., and Shearn, M. A. (1952). Arch. intern. Med., 90, 217.

Bywaters, E. G. L., and Ansell, B. M. (1958). Ann. rheum. Dis., 17, 169.

- Carter, M. E., and Scott, F. E. T. (1959). Ibid., 18, 225.

Church, R. (1958). Brit. J. Derm., 70, 139.

Edström, G., Thune, S., and Wittbom-Cigén, G. (1960). Acta rheum. scand., 6, 161.

Green, W. T., and Banks, H. H. (1953). J. Bone $J t$ Surg., 35A, 26.

Hart, F. Dudley (1955). Ann. rheum. Dis., 14, 77.

Hollister, L. E., and Engleman, E. P. (1958). J. chron. Dis., 8, 334.

Isdale, I. C., and Bywaters, E. G. L. (1956). Quart. J. Med., 25, 377.

Jacobs, A. G. (1961). Brit. med. J., 2, 155.

King, R. C., Lindner, A. E., and Pollard, H. M. (1959). Arch. Dis. Childh., 34, 257.

McMinn, F. J., and Bywaters, E. G. L. (1959). Ann. rheum. Dis., 18, 293.

Morse, T. S., and Pryles, C. V. (1960). New Engl. J. Med., 262, 846.

Platt, J. W., Schlesinger, B. E., and Benson, P. F. (1960). Quart. J. Med., 29, 257.

Scott, J. T., Hourihane, D. O., Doyle, F. H., Steiner, R. E., Laws, J. W., Dixon, A. St. J., and Bywaters, E. G. L. (1961). Ann. rheum. Dis., 20, 224.

Smith, A. D. (1960). J. Bone Jt Surg., 42A, 289.

Steinberg, V. L., and Storey, G. (1957). Brit. med. J., 2, 1157.

Wright, V. (1956). Ann. rheum. Dis., 15, 348.

Diagnostic de la maladie de Still "probable" et son issue

\section{RÉSUMÉ}

Sur 43 cas présentant des traits indicatifs de la maladie de Still, vus avant le mois de Janvier, 1959, et suivis jusqu'à présent, 5 dévéloppèrent la maladie de Still classique et dans 15 autres cas on arriva à d'autres diagnostics, tels que l'arthrite psoriasique, colite ulcérative, spondylarthrite ankylosante, lupus érythémateux disséminé, sclérodermie et dermatomyosite.

Pendant la même période on vit 219 cas de maladie de Still confirmée (par définition); seulement deux d'entre eux durent être éliminés de cette catégorie parce qu'ils dévéloppèrent un psoriasis.

Les 23 cas qui restent dans la catégorie de "maladie de Still probable" peuvent être divisés en trois groupes:

(a) ceux avec oligoarthrite, mais ayant des lésions articulaires résiduelles;

(b) ceux atteints d'une polyarthrite plus généralisée mais passagère, avec des lésions résiduelles minimes; il peut bien s'agir ici d'une forme benigne de la maladie;

(c) ceux qui débutèrent par des symptômes généraux et se remirent complètement; ils eurent probablement une forme fruste.

Cependant, étant donné que presqu'un tiers des malades classés au début comme cas de "maladie de Still 
probable" furent rangés à la suite dans d'autres catégories, il serait prudent, en tout cas lorsqu'on fait des recherches, de continuer à appliquer des critères précis avant d'affirmer le diagnostic.

\section{El diagnóstico de la enfermedad de Still "probable" y sus consecuencias}

\section{Sumario}

Rasgos indicativos de la enfermedad de Still fueron notados antes del mes de enero de 1959 en 43 enfermos, que fueron observados hasta la hora reciente. Entretanto cinco de ellos desarrollaron una enfermedad de Still clásica y en otros quince se llegó a otros diagnósticos, tales como artritis psoriásica, colitis ulcerativa, espondilartritis anquilosante, lupus eritematoso diseminado, esclerodermia y dermatomiositis.

Durante el mismo período se vieron 219 casos de enfermedad de Still confirmada (por definición). Se tuvo que eliminar de esta categoría diagnóstica solamente dos casos que desarrollaron una psoriasis.

Los 23 casos que quedan en la categoría de "enfer" medad de Still probable" se pueden dividir en tres: grupos:

(a) los con oligoartritis, pero con lesiones articulares residuales;

(b) los con poliartritis más generalizada pero transitoria y lesiones residuales mínímas; sef trata aquí probablemente de una forma benignad de la enfermedad;

(c) los que comenzaron con manifestaciones» generales y recobraron completamente; probablemente tuvieron la forme fruste de la enfermedad.

Sin embargo, como casi una tercera parte de los en $\vec{\omega}$ fermos clasificados como casos de enfermedad de Stilf probable fué luego transferida a otras categorías, parecé prudente, particularmente con el objeto de investi gación, seguir empleando criterios precisos antes confirmar el diagnóstico. 